\title{
History and experience in Elena Mauli Shapiro's 13 rue Thérèse: How do we get to know the past?
}

\author{
EWA FIUTKA
}

Received 31.01.2018,

received in revised form 24.07.2018, accepted 30.11.2018.

\begin{abstract}
Elena Mauli Shapiro in 13 rue Thérèse asks questions about the ways of mediating the past. The problem is by no means new but the author attempts to present historical events through the category of historical experience as a valid manner of showing the past. Therefore, the novel is looked upon from the perspective of Frank Ankersmit's concept of experience as well as the theory of objects as tools which assist the recipient in mediating the past. Thus, both through the use of the category of experience and the presentation of history through objects, the past is presented as fragmented and unreliable, which in fact reflects how historical writing is perceived nowadays, especially if the ending of the novel suggests that the past is inevitably linked with the present.
\end{abstract}

\section{Keywords}

Elena Mauli Shapiro, 13 rue Thérèse, historical experience, Frank Ankersmit, objects 


\title{
Historia i doświadczenie w powieści Eleny Mauli Shapiro 13 rue Thérèse: Jak poznajemy przeszłość?
}

\begin{abstract}
Abstrakt
Elena Mauli Shapiro w 13 rue Thérèse stawia pytania dotyczace sposobów pośredniczenia przeszłości. Problem zdecydowanie nie jest nowy, ale autorka próbuje przedstawić wydarzenia historyczne poprzez kategorię doświadczenia historycznego jako jednego $z$ możliwych sposobów ukazywania przeszłości. Dlatego też powieść jest analizowana $z$ perspektywy koncepcji doświadczenia Franka Ankersmita oraz teorii przedmiotów jako narzędzi wspomagających odbiorce w pośredniczeniu przeszłości. Stąd też zarówno dzięki zastosowaniu kategorii doświadczenia, jak i przedstawieniu historii poprzez przedmioty, przeszłość jest ukazana jako fragmentaryczna i niewiarygodna, co w istocie odzwierciedla obecny sposób postrzegania pisarstwa historycznego, zwłaszcza że zakończenie powieści sugeruje, iż przeszłość jest nieuchronnie powiązana $z$ teraźniejszościa.
\end{abstract}

\section{Slowa kluczowe}

Elena Mauli Shapiro, 13 rue Thérèse, doświadczenie historyczne, Frank Ankersmit, przedmioty

The beginning of the twenty-first century is marked by a shift of focus in the perception of historiography and historical narrative. Although the findings presented by Hayden White in Metahistory (1973) are still valid for the theory of historiography, i.e. the concept of multiple accounts of the past none of which actually represents the correct image of this past, nowadays there is a new tendency, to look at history through the category of experience. This category does not exclude a traditional approach to history as a discipline but actually enriches it and gives an alternative means of mediating the past. Frank Ankersmit (2001: 152) emphasises that nowadays history as a discipline is disintegrating both ontologically and epistemo- 
logically. The past is no longer perceived as a whole but rather as a sum of independent versions of it. As a result, one is unable to indicate which element of the past is significant or irrelevant as they could be both, depending on the historian's intentions and the concept of the work. An example for such a treatment of the past is provided by so-called microhistories that present the past from the perspective of an average person, unlike grand narratives which focus on leaders and great events, mainly of a political nature.

The trend to show history through experience is not solely confined to the discipline of history but has an even greater reflection in literature and literary studies. The issues of how to get to know and represent the past are highlighted in postmodern historical fiction, particularly historiographic metafiction which "destabilises received notions of both history and fiction" (Hutcheon 1988: 120). However, as Mitchell (2010) notes, nowadays there is a growing tendency towards what she calls "memory texts" (32) which mediate the past by means of memory objects. For this purpose, the category of experience is frequently used as a means of mediating the past which is more effective than language, as the latter is imperfect by its nature and may be less straightforward. Elena Mauli Shapiro in her novel 13, rue Thérèse makes use of this approach and poses questions about ways of mediating the past. She also raises issues concerning the objectivity of historical accounts. The problem is by no means new but the author attempts to present historical events through the category of experience as a valid manner of showing the past. Therefore, in this article the novel is looked upon from the perspective of Frank Ankersmit's concept of historical experience. The theory of objects is also applied as it may serve as an analytical tool for the interpretation of the text since photographs of objects are provided in the novel to assist the recipient in mediating the past.

Shapiro in her novel presents the past through the vehicle of a text combined with images of artefacts which reinforce the message of the novel. The device is not new - Edward Bulwer 
Lytton's The Last Days of Pompeii, one of the most successful Victorian novels, describes the events after the eruption of Vesuvius in $79 \mathrm{AD}$. The story is based on the last moments of two characters whose real skulls can still be found in Lytton's house - the skulls of Arbaces and Calenus (Goldhill 2015: 10). They serve to corroborate the truth of the fictional story and to show history to the viewer and the reader.

A similar device is applied in 13, rue Thérèse. The story of the main character of the novel, Louise Brunet, is inspired by that of a real person with the same name who indeed lived and died in the house at 13, rue Thérèse in Paris. As she did not have any relatives, her possessions were taken by her neighbours - Shapiro's mother took Louise's cardboard box with her personal belongings. The novel provides descriptions of these items, accompanied by images of the artefacts. They are mostly letters and photographs of the protagonists, but also a picture of a calendar, gloves, or such odd items as a bullet pencil case. The author presents a plausible version of Louise's life on the basis of the objects which make the story more alive but, most of all, more true-to-life. Such a device strengthens the reception of the past experienced by the reader who, contrary to an indifferent attitude which could result from contact with the textual version only, approaches the past more emotionally when faced with a story supported with the actual artefacts left behind by real figures. This type of encounter with objects might be called a historical experience of these artefacts.

The category of experience has been discussed in the literature since ancient times but historical experience is rather rarely mentioned, especially in literary criticism. Although Oakeshott (1933) had earlier called history a form of experience, and other historians, like Gibbon or Toynbee, mentioned their personal experience as being influential in their writing of history (van der Dussen 2016: 238), it is Ankersmit (2005: 124-125), inspired by Huizinga and his concept of historical sensation, who fully developed the concept of historical 
experience as a moment of immediate contact with an artefact from the past. The subject (the receiver of the experience) and the object (be it a painting, sculpture, building, or everyday object from the past) do not form separate entities at the moment of this sensation but make up a unity. The separation takes place only after that moment. The experiential contact between the subject and the object is possible thanks to the senses of smell and hearing rather than eyesight. Another essential element of historical experience is its decontextualisation - the object should be little known or unknown to academia so that previous interpretations cannot influence a first unmediated contact with the object. This is why historical experience is virtually impossible with famous artefacts as they are already situated in the context of scientific research and evaluation. Historical experience also takes place unexpectedly so it is only possible with random objects and, therefore, the subject is not prepared in any way for this encounter. Historical experience, for Ankersmit (2005: 128), should also be distinguished from historical intuition in which the past is shaped by the historian while in historical experience it is the past that influences the historian.

Shapiro's presentation of the images of various artefacts in the novel seems to share some of the features of historical experience as seen by Ankersmit. First of all, the objects presented in 13, rue Thérèse are random and decontextualised. They are not familiar to the modern character of the novel, a researcher called Trevor Stratton, who aims at discovering the story behind these objects. He endeavours to put together particular elements of the puzzle in order to organise them into a coherent early-twentieth-century story whose main protagonist is Louise Brunet. Therefore, the objects in the novel are not only unknown to the researcher but also deprived of any context which could equip them with meaning. This meaning is first given by Stratton who arranges the objects into a meaningful chronological unity and invents the story behind them on the basis of his research. Thus, the objects determine the 
story so it is the past that influences the researcher, as in historical experience. Yet, as White (1973: 6-7) argues, the historian, through the interpretation of past events and their organisation into a meaningful story, partially creates these events as well. This, however, does not happen at the moment of historical experience but afterwards, when the researcher (the subject) is separated from the object and starts to think independently, also applying elements of historical intuition. In the novel, historical experience is mediated through Trevor's research and his presentation of the objects, but it is actually Shapiro as the writer who creates the past in the novel, thus facilitating historical experience for the reader. She makes use of the real Louise Brunet's personal possessions in order to introduce the reader to the period in which Brunet lived.

This experience is made possible through the introduction of the images of the artefacts both in the novel and the website devoted to 13, rue Thérèse (13ruetherese.com). The focus, therefore, is on seeing the artefacts, unlike in historical experience which foregrounds the senses of smell and hearing. Nonetheless, the website also provides pieces of music, connected with the story, to be listened to. The novel itself also contains sheet music for these pieces which may later be played by the readers (Shapiro 2011: 193, 218). Moreover, on the website, the reader can find a recipe for boeuf bourguignon with potatoes served by Louise to her husband Henri, so not only the sense of hearing but also the sense of taste and smell may be satisfied, which concurs with Ankersmit's idea of historical experience, sensed in multiple ways.

Thus, thanks to the introduction of various forms of objects, appealing to various senses, the reader is allowed physical contact with the past even though, in the novel, artefacts are only represented by their images. However, the photographs themselves can also serve as objects mediating the past. As Roland Barthes (1981) observed, photographs represent death as they depict what has already happened but, at the same time, they render the photographed dead figure alive. Thus, 
they bring the observer closer to the past they convey and become carriers of the story. This phenomenon finds its confirmation in the Afterword of the novel: "This box is the sepulchre of Louise Brunet's heart. The story behind the objects is lost; the objects are now the story" (Shapiro 2011: 275). This indicates the vital role of objects in retrieving the past, in particular when their story is otherwise left unrecorded. The reader's role (through the figure of Trevor Stratton), on the other hand, is to decipher the meaning of specific objects for their former owner, Louise Brunet.

Thus, the objects become essential tools, necessary in retrieving past events both by Stratton and the reader, and because of this the relationship between the objects and the observer is not passive. Pearce (1994: 26) argues that there is a constant interaction between the object equipped with certain properties and the viewer who, based on his/her past experience, reacts to the object and imposes certain meanings on it. What is more, the observer may approach the object differently at different times - therefore, artefacts are actually transformed into experience, they are like mirrors reflecting the changes of the observer's attitude to them. A similar approach is taken by Joyce (2002: 142) who believes that her role is "to evaluate, revoice, and to make a response" to objects. Thus, the major significance of objects from the past consists in their ability to enter into an interaction with present subjects. Wood and Latham (2014) also emphasise the mutual influence of the object and the subject. This relationship is called a "unified experience" (32), which suggests a temporary unity between the viewer and the object rather than an interaction in which two agents are separate. Such a presentation of the objectsubject connection coincides with Ankersmit's concept of historical experience which also indicates a moment of unity between the two elements.

The idea of unity between the object and the subject is actually the concept which enables the unmediated contact of the present with the past in the novel. Objects evoke memories 
from the past in the form of historical experience both in Trevor Stratton and the reader. Such a phenomenon is exemplified by the introduction of the cardboard box with Louise's possessions which Stratton uses to transfer himself to the year of 1928. Thus, Stratton is allowed unmediated contact with the past. Readers can also access the past through the objects which serve as carriers of past experience, e.g. letters from Camille, Louise's cousin and lover, to Louise. The sensation is reinforced by the fact that the letters are included in the novel both within the text and as photographs of them (e.g. Shapiro 2011: 63-65). Thus, the reader may actually see and experience the letters just as Louise did.

Although the reader is allowed unmediated contact with the past through the introduction of contemporary objects, the novel is still permeated with the belief that it is impossible to retrieve the past. Henri, Louise's husband, having seen two people lighting each other's cigarettes, wonders whether they ever finished the action and concludes: "There is no way to know, is there?" (Shapiro 2011: 266). His statement returns to the idea of the impossibility of retrieving the past, especially if there is no information about the event in question. Louise's answer strengthens this conviction: "That information is not in the documentation" (Shapiro 2011: 266). This suggests that there are gaps in our knowledge about the past and no evidence is provided for some past events. Interestingly, the statement repeats the words uttered by Stratton earlier in the novel: "[NB: This is not a part of documentation; it is just a page spread from a book.]" (Shapiro 2011: 98). This fragment refers to the photograph of a page from the book mentioned by one of the characters, Xavier. Although theoretically this fact strengthens the reader's experience of the past as the story is supported with a real object, at the same time the information about the book does not exist in the researched documents, which undermines the truth conveyed through this inclusion. A similar device is used in the case of the sheet music which Garance, Louise's student, gave her teacher. The novel pro- 
vides an image of the page with the notes followed by such information: "[NB: This is a negative image of a document that does not exist.]" (Shapiro 2011: 218). This statement creates a sense of uncertainty in the reader who is no longer able to distinguish between the truth and fictional elements in the novel. Paradoxically, this uncertainty strengthens the intensity of historical experience in readers as the information comes to them unexpectedly and they become aware that they have access to knowledge which is otherwise inaccessible to others.

The strength of this historical experience is emphasised in one of the footnotes where Travis Stratton gives his personal comment: "I am sick again, [...] The images come and I am so frightened, but it is not my fear that I feel. It is yours. I am you on that day, November 3, 1915. We are Camille Victor [...]" (Shapiro 2011: 152). This quotation is followed by a footnote which provides a description of the First World War trenches and Camille's war experience. Therefore, again the readers are allowed access to knowledge which should not be presented to them as there is no historical evidence which would prove the veracity of this information. However, this time the historical experience is presented in its purest form - unexpectedly, the subject (the reader) becomes united with the object (Trevor Stratton and, through him, Camille) in their feelings and thoughts. This time it is not the artefact that mediates the experience but the act of reading and contact with the characters of the novel.

What is interesting in the aforementioned example is the fact that the historical experience is triggered by a footnote. Generally, footnotes are introduced in the novel to perform the same function as they serve in scientific discourse. They provide additional information which otherwise would not fit the arrangement of the main text. Yet, they also often contain information which does not have any reflection in historical evidence, e.g. Louise's father's violent reaction to Camille's request to marry Louise (Shapiro 2011: 75) which is not mentioned in any of the letters found in Louise's box. Therefore, on 
the one hand, bearing in mind the fact that the novel is a fictional genre, the footnotes give the impression of academic discourse and scientific objectivity, typical of non-fictional writing. On the other hand, however, the use of footnotes is another element which questions the veracity of the presentation of the events in the novel. The question arises in the reader's mind as to the source of Travis Stratton's knowledge about the characters. This puzzle is solved only later in the novel when it turns out that Stratton is actually the creator of the whole story and the characters are the invention of his imagination.

In spite of the impossibility of retrieving the past, the novel indicates solutions for this plight, namely the writer's imagination and the ability to creatively fill in the gaps in our knowledge about the past. What is presented to the reader is just an interpretation of past events which involves elements of creation, more typical of literature than scientific discourse. The case is exemplified in the novel by Trevor Stratton's conversation with Louise when he transfers himself to her times. Stratton tells her he saw Camille dying in the trenches of the First World War and read him a letter Louise had not actually written. Stratton finishes his story with the comment: "I did what I always do. I falsified" (Shapiro 2011: 257). Thus, he emphasises the fictional aspect of history writing and indicates that due to the lack of information and possible gaps in his/her knowledge about the past, the historian (or the writer of history) is forced to invent the story to arrange the events in it in a logical and consistent manner. This conviction is strengthened by the fact that, in the conversation with Louise, Stratton calls her "his research" (Shapiro 2011: 253), which indicates that he treats her as another object to be studied in his endeavour to learn about past events.

The Afterword of the novel further emphasises the fictional character of any historical writing: "The Louise Brunet depicted within it is a fiction; the real Louise Brunet is irretrievable. Still, she gave me the stars. I merely drew the constellations" (Shapiro 2011: 275). This indicates the impossibility of retriev- 
ing the past and the writer's (historian's) task to somehow invent past events by imposing certain interpretations. In fact, past events may become solely an inspiration to writing a story, as is the case in 13, rue Thérèse. This role is reinforced by the ending of the novel. Trevor Stratton turns out to have invented the story himself and the letters he writes to his principal to show progress in his research are in fact addressed to himself. Therefore, the ending of the novel emphasises the partly fictional nature of historical writing in the face of the irretrievability of the past. However, it also indicates that the past is inevitably linked with the present which shapes the image of the past.

The appeal of the story in 13, rue Thérèse by Elena Mauli Shapiro is based on a mixture of real and fictional elements. The reception of this combination by the reader is strengthened through the use of the category of historical experience and the presentation of history through existing objects. As a result, the reader feels uncertain as to the course of events and their veracity. The introduction of historical experience through visual contact with real objects allows for the presentation of the past as fragmented and unreliable, which in fact reflects the manners of perception of the past nowadays. This phenomenon is emphasised particularly in the ending of the novel which suggests the inevitable link of the past with the present in any historical writing, be it a novel or historical non-fiction. This connection unavoidably means that fiction is also linked with reality just as it is in the case of 13 , rue Thérèse.

\section{References}

13, rue Thérèse. Available at <http://13ruetherese.com/>. Accessed 20.10.2017.

Ankersmit, Frank (2001). Historical Representation. Stanford: Stanford University Press. 
Ankersmit, Frank (2005). Sublime Historical Experience. Stanford: Stanford University Press.

Barthes, Roland (1981). Camera Lucida: Reflections on Photography. Trans. Richard Howard. New York: Hill and Wang.

Goldhill, Simon (2015). The Buried Life of Things: How Objects Made History in Nineteenth-Century Britain. Cambridge: Cambridge University Press.

Hutcheon, Linda (1988). A Poetics of Postmodernism: History, Theory, Fiction. New York and London: Routledge.

Joyce, Rosemary, et al. (2002). The Languages of Archaeology: Dialogue, Narrative, and Writing. Malden: Blackwell Publishers Ltd.

Mitchell, Kate (2010). History and Cultural Memory in Neo-Victorian Fiction: Victorian Afterimages. Houndmills: Palgrave Macmillan.

Oakeshott, Michael (1933). Experience and Its Modes. Cambridge: Cambridge University Press.

Pearce, Susan M. (1994). "Objects as meaning; or narrating the past”. In: Susan M. Pearce (ed.). Interpreting Objects and Collections. London and New York: Routledge. 19-28.

Shapiro, Elena Mauli (2011). 13, rue Thérèse. New York: Little, Brown and Company.

Van der Dussen, Jan. (2016). Studies on Collingwood, History and Civilization. New York: Springer International Publishing.

White, Hayden (1973). Metahistory: The Historical Imagination in Nineteenth-Century Europe. Baltimore: The Johns Hopkins University Press.

Wood, E. \& Latham, K.F. (2014). The Objects of Experience: Transforming Visitor-Object Encounters in Museums. Walnut Creek, CA: Left Coast Press, Inc.

Ewa Fiutka

ORCID iD: 0000-0002-9568-4403

Pope John Paul II State School of Higher Education in Biała Podlaska

ul. Sidorska 95/97

21-500 Biała Podlaska

Poland

ewax@poczta.onet.p1 